\title{
Proprioceptive-induced (stimulus-sensitive) reflex seizures
}

Gustavo Fernandes, MD, MSc, Gerado Rizzo, MD, Luiz Nelson Fernandes, MD, MSc, and Brendon Popinhak, MD

Neurology ${ }^{\circledR}$ 2020;94:89-90. doi:10.1212/WNL.0000000000008791

Figure EEG shows epileptiform discharges in the left frontotemporal region during voluntary movement of the right lower limb

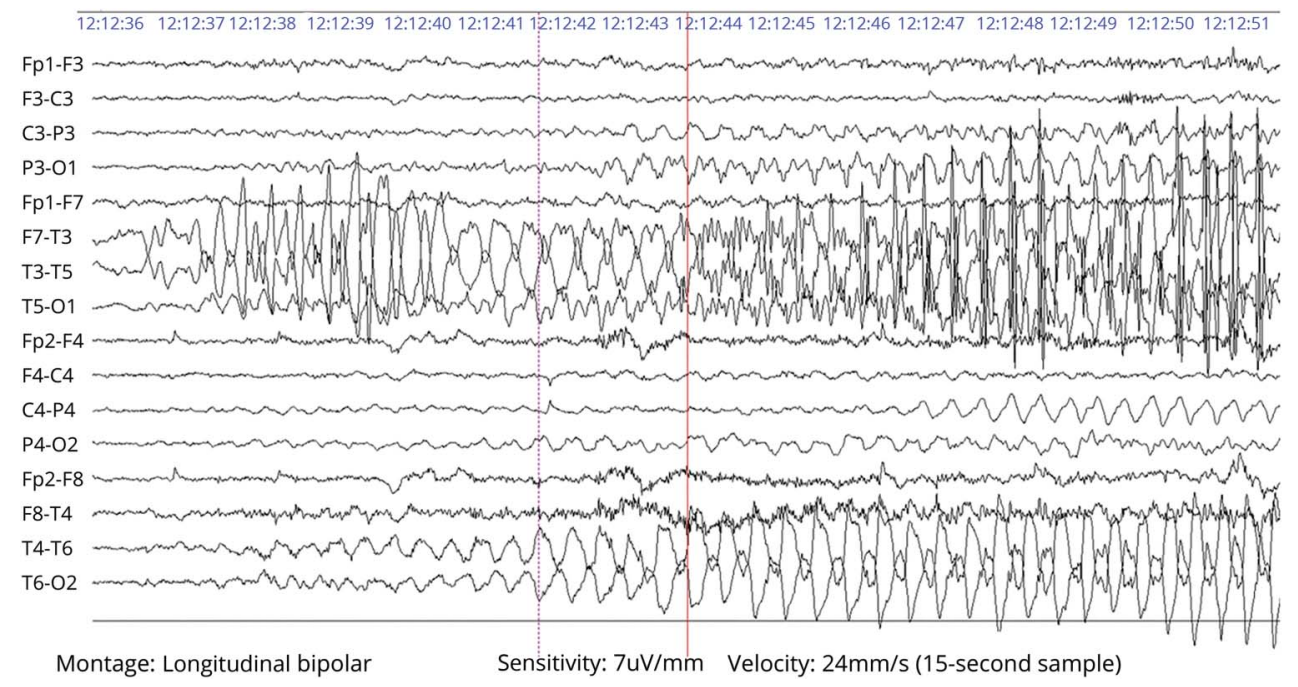

A 78-year-old man presented with abnormal right leg movements 2 days after mild traumatic brain injury. He displayed clonic movements of the right leg after a few seconds of voluntary movement of the same leg, lasting about 20 seconds. Brain MRI showed a small subarachnoid hemorrhage in the cerebral convexities. EEG at rest was normal but demonstrated robust epileptiform discharges in the left frontotemporal region (figure) after voluntary movements of the right leg (video 1). Seizures subsided with clobazam $20 \mathrm{mg} / \mathrm{d}$. Reflex seizures have been described with various triggers and etiologies. 1,2

\section{Author contributions}

G.C. Fernandes: drafting/revising the manuscript, study concept or design, accepts responsibility for conduct of research and final approval, acquisition of data. G. Rizzo: analysis or interpretation of data, accepts responsibility for conduct of research and final approval, acquisition of data. L.N. Fernandes: drafting/revising the manuscript, accepts responsibility for conduct of research and final approval, diagnosis formulation. B. Popinhak: drafting/revising the manuscript, accepts responsibility for conduct of research and final approval, acquisition of data.
Correspondence

Dr. Fernandes

gcostafernandes@

yahoo.com
MORE ONLINE

Q Video 


\section{Study funding}

No targeted funding reported.

\section{Disclosure}

The authors report no disclosures relevant to the manuscript.

Go to Neurology.org/N for full disclosures.

\section{References}

1. Szücs A, Rosdy B, Kelemen A, Horvath A, Halasz P. Reflex seizure triggering: learning about seizure producing systems. Seizure 2019;69:25-30.

2. Wolf P. Reflex epileptic mechanisms in humans: lessons about natural ictogenesis Epilepsy Behav 2017;71:118-123.

\section{Sign Up for the AAN's Axon Registry}

The AAN encourages its US members to show their interest in participating in the Axon Registry by signing up today.

Use the Axon Registry to:

- Simplify reporting requirements under MACRA's Quality Payment Program and avoid penalties while reducing your administrative burden

- Meet your MOC Part IV requirements and waive up to eight credits of Part II Self-Assessment

- Choose from 22 AAN neurology-specific quality measures that fit your practice

- Use data to understand your practice and identify where improvements can be made to patient care

- Manage your patients at a population level; look at a specific group of patients based on conditions, risk factors, demographics or outcome

- Demonstrate your value to payers when negotiating reimbursement

- Enjoy multi-year, fee-free access when you sign the agreements and integrate your EHR with the registry

Learn more at AAN.com/view/Axon and send your questions to registry@aan.com.

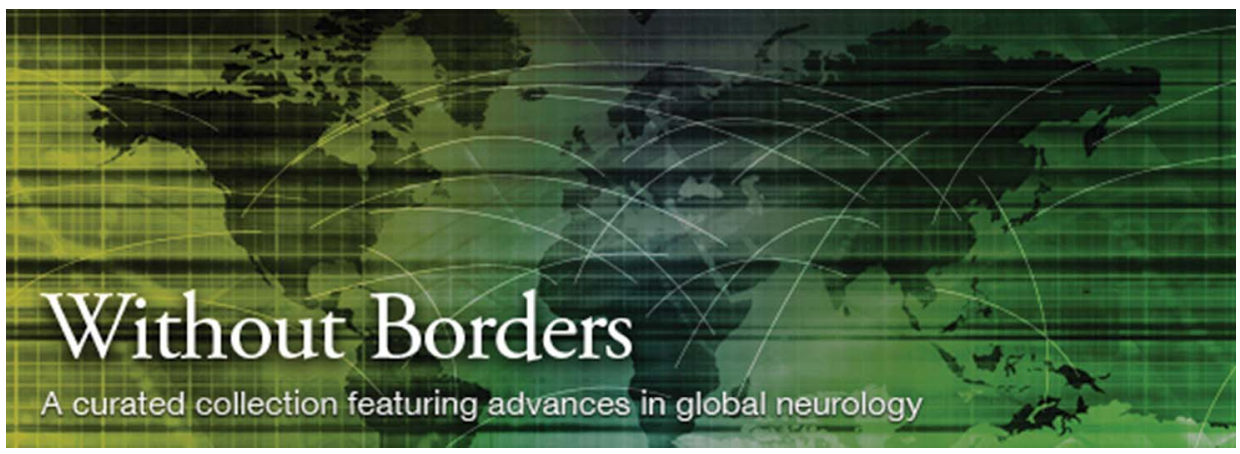

\section{Without Borders - A curated collection featuring advances in global neurology}

This Neurology ${ }^{\circledR}$ special interest website is the go-to source for tracking science and politics of neurology beyond the United States, featuring up-to-the-minute blogs, scholarly perspectives, and academic review of developments and research from Neurology journals and other sources. Curated by Gretchen L. Birbeck, MD, MPH.

Expand your world view at Neurology.org/woborders. 


\title{
Neurology
}

\author{
Proprioceptive-induced (stimulus-sensitive) reflex seizures \\ Gustavo Fernandes, Gerado Rizzo, Luiz Nelson Fernandes, et al. \\ Neurology 2020;94;89-90 \\ DOI 10.1212/WNL.0000000000008791
}

This information is current as of January 13, 2020

\section{Updated Information \& Services}

\section{References}

Subspecialty Collections

\section{Permissions \& Licensing}

Reprints including high resolution figures, can be found at: http://n.neurology.org/content/94/2/89.full

This article cites 2 articles, 0 of which you can access for free at: http://n.neurology.org/content/94/2/89.full\#ref-list-1

This article, along with others on similar topics, appears in the following collection(s):

\section{All Education}

http://n.neurology.org/cgi/collection/all_education

Clinical neurology examination

http://n.neurology.org/cgi/collection/clinical_neurology_examination EEG

http://n.neurology.org/cgi/collection/eeg

Epilepsy semiology

http://n.neurology.org/cgi/collection/epilepsy_semiology

Video/ EEG use in epilepsy

http://n.neurology.org/cgi/collection/video_eeg_use_in_epilepsy

Information about reproducing this article in parts (figures,tables) or in its entirety can be found online at:

http://www.neurology.org/about/about_the_journal\#permissions

Information about ordering reprints can be found online:

http://n.neurology.org/subscribers/advertise

Neurology ${ }^{\circledR}$ is the official journal of the American Academy of Neurology. Published continuously since 1951, it is now a weekly with 48 issues per year. Copyright (O) 2020 American Academy of Neurology. All rights reserved. Print ISSN: 0028-3878. Online ISSN: 1526-632X.

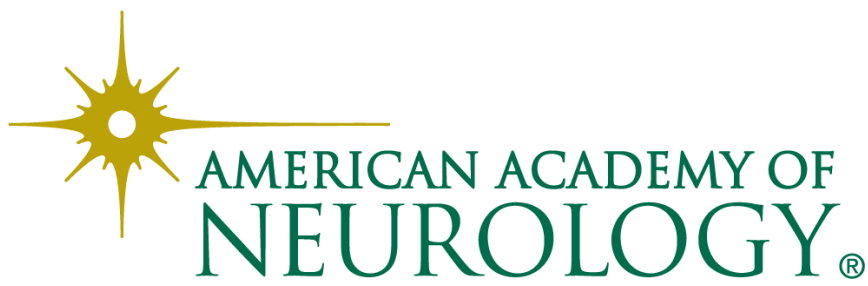

